\title{
ISOLASI DAN IDENTIFIKASI KHAMIR THERMOTOLERANT DAN ETHANOL- TOLERANT PADA BUAH LOKAL INDONESIA
}

\section{Isolation and Identification of Thermotolerant and Ethanol-tolerant Yeast on Indonesian Local Fruits}

\author{
Mochamad Nurcholis, Dendy Fernando, Elok Zubaidah, Jaya Mahar Maligan* \\ Jurusan Teknologi Hasil Pertanian, FTP Universitas Brawijaya Malang \\ Jl. Veteran, Malang 65145 \\ *Penulis Korespondensi, Email: maharajay@gmail.com
}

\begin{abstract}
ABSTRAK
Penelitian ini bertujuan memperoleh isolat khamir penghasil etanol yang memiliki toleransi tinggi terhadap etanol dan suhu. Tahapan dalam penelitian ini meliputi isolasi khamir, identifikasi morfologi koloni dan sel, analisis kurva pertumbuhan khamir, skrining khamir thermotolerant dan ethanol-tolerant, fermentasi dan analisis kadar etanol. Isolat JCBI-01 (Kenitu) dan JCBI-14 (Coklat) diduga genus Candida sp. Sedangkan isolat JCBI-02 (Pisang) dan JCBI-03 (Pepaya) diduga genus Saccharomyces sp. Pada uji ethanol-tolerant isolat JCBI01, JCBI-02, JCBI-14, dan JCBI-03 memiliki toleransi yang baik terhadap etanol konsentrasi $14 \%$, dan pada isolat $\mathrm{JCBI}-01$ dan $\mathrm{JCBI}-14$ masih dapat toleran pada konsentrasi $15 \%$. Hasil uji thermotolerant semua isolat bertahan hingga suhu $48^{\circ} \mathrm{C}$. Untuk kemampuan dalam produksi etanol pada jam ke-48, isolat JCBI-01 menghasilkan etanol sebesar $2.41 \%(\mathrm{~b} / \mathrm{v})$, JCBI-02 sebesar 2.54\% (b/v), JCBI-14 sebesar 2.63\% (b/v), dan JCBI-03 sebesar 3.07\% (b/v).
\end{abstract}

Kata kunci: Bioetanol, Ethanol-tolerant, Isolasi khamir, Thermotolerant

\section{ABSTRACT}

This study aims to isolate ethanol-producing yeasts having high tolerance to ethanol concentrations and temperatures. This research steps were yeast isolation, morphology identification of colonies and cells, yeast growth curve analysis, screening of thermotolerant and ethanol-tolerant yeast, ethanol fermentation and analysis. The results showed that isolates JCBI-01 (Star apple) and JCBI-14 (Chocolate) were thought to be Candida sp. Whereas isolates JCBI-02 (Banana) and JCBI-03 (Papaya) were thought to be Saccharomyces sp. In ethanol-tolerant analysis isolates JCBI-01, JCBI-02, JCBI-14 and JCBI03 had a tolerance to ethanol 14\%, and isolates JCBI-01 and JCBI-14 were tolerance at a concentration of $15 \%$. Whereas in the thermotolerant analysis all isolates were tolerance to a temperature of $48^{\circ} \mathrm{C}$. For the ability in the production of ethanol at $48 \mathrm{~h}$, isolates JCBI-01 produced ethanol $2.41 \%(w / v)$, JCBI-02 was $2.54 \%(w / v), J C B I-011_{4}$ was $2.63 \%(w / v)$, and JCBI-03 at $3.07 \%(w / v)$.

Keywords: Bioethanol, Ethanol-tolerant, Yeast isolation, Thermotolerant

\section{PENDAHULUAN}

Saat ini cadangan minyak bumi di dunia termasuk Indonesia memiliki tren menurun. Pada tahun 2014 mencapai 7,375.10 Million Stock Tank Barrels (MMSTB), terakhir tahun 2015 mencapai 7,305.02 MMTSB. Berdasarkan data tersebut terdapat tren penurunan cadangan minyak bumi di Indonesia pada kurun waktu 2011-2015. Sedangkan kebutuhan minyak dalam bentuk Bahan Bakar Minyak terus meningkat. Pada tahun 2010 mencapai 68,14 juta KL, pada tahun 2011 mengalami kenaikan 4.04\% yakni mencapai 70,89 juta. Produksi Bahan Bakar Minyak (BBM) Indonesia pada tahun 2012 hanya mencapai 22,173.37 
juta KL (ESDM, 2015), data tersebut mengakibatkan Indonesia defisit bahan bakar dan harus mengimpor sebanyak 48,716 juta KL (Kementerian ESDM, 2016). Fakta ini akan membuat Indonesia akan terus mengimpor BBM dalam jumlah yang besar setiap tahun. Pengembangan sumber energi yang dapat diperbarui, seperti air, mini/mikro hydro, angin, panas bumi, sinar matahari, biomasa, dan bahan bakar nabati (BBN) perlu dilakukan. BBN yang banyak dikembangkan adalah biodiesel dan bioetanol. Pada pembuatan bioetanol terdapat proses fermentasi gula yang dihasilkan oleh khamir.

Khamir memiliki kekurangan yakni memiliki sensitivitas terhadap etanol konsentrasi tinggi (diatas $10 \%$ ) dan juga tidak tahan terhadap suhu diatas $40^{\circ} \mathrm{C}$. Pada kemampuan ethanol-tolerant, Tikka et al (2013) menyatakan jika secara umum khamir yang diuji berada pada level toleransi etanol dengan konsentrasi $0 \%$ sampai $12 \%(v / v)$. Sejauh ini khamir yang mampu untuk memfermentasi gula dan molases pada suhu $48^{\circ} \mathrm{C}$ hanya khamir Kluyveromyces marxianus strain DMKU3-1042 yang diisolasi di Thailand (Limtong et al, 2007; Keo-oudone et al, 2016). Problem di industri yang memproduksi etanol yaitu kemampuan khamir jenis S. cerevisiae pada suhu $35-45^{\circ} \mathrm{C}$ dan tahan konsentrasi etanol kurang dari $20 \%$ (Banat et al, 1998). Keuntungan dari fermentasi etanol pada suhu tinggi yaitu menurunkan resiko kontaminasi mikroorganisme lain, menurunkan biaya proses pendinginan dan hidrolisis enzimatis, sakarifikasi dan fermentasi secara simultan (Limtong et al, 2007; Kosaka et al, 2018; Murata et al, 2015). Selain itu metabolit berupa asam asetat yang dihasilkan selama fermentasi pada suhu tinggi dapat menghambat pertumbuhan khamir jenis $K$. marxianus DSM 5422 (Martynova et al, 2016).

Beberapa jenis khamir baru yang memiliki toleransi terhadap suhu dan etanol konsentrasi tinggi perlu dikembangkan. Indonesia merupakan negara tropis dengan keanekaragam hayati lokal yang melimpah diantaranya buah-buahan, sayuran, serealia, kacang-kacangan dan umbi-umbian. Pada penelitian ini isolasi khamir dilakukan dari buah lokal Indonesia, karena komoditas ini memiliki kandungan gula yang tinggi dan sesuai untuk pertumbuhan khamir. Eksplorasi ini diharapkan dapat menghasilkan isolat khamir dengan kemampuan thermotolerant dan ethanol-tolerant yang tinggi sehingga bermanfaat untuk produksi etanol di negara tropis.

\section{BAHAN DAN METODE}

\section{Bahan}

Bahan yang digunakan pada penelitian ini yaitu buah lokal Indonesia diantaranya kenitu, pisang, pepaya, sawo, manggis, nangka, kesemek, siwalan, bit, mangga gadung, bengkuang, mangga manalagi, mangga podang, cokelat yang diperoleh dari pasar di kota Malang. Media yang digunakan dalam penelitian ini adalah YPGA ( Yeast extract Peptone Glucose Agar) dan YPGB (Yeast extract Peptone Glucose Broth), akuades, aseton, alkohol $70 \%$, Cloramphenicol $0.05 \%$, reagen pewarnaan methylene blue, minyak imersi, aquades, kapas dan spiritus.

\section{Alat}

Alat yang digunakan pada penelitian ini yaitu autoclave (DEA), vortex (Benchmark Scientific), laminar air flow (Innotech), timbangan analitik (Mettler), kompor listrik (maspion), incubator (Memmert), sentrifuge dingin (Fisher Sci), shaker waterbath (Memmert), Gas Chromatography (Shimadzu), mikroskop (Olympus), lemari pendingin, bunsen, jarum ose, dan glassware seperti beaker glass, erlenmeyer, gelas ukur, pipet ukur, tabung reaksi dan cawan petri.

\section{Desain Penelitian}

Dalam penelitian ini menggunakan metode deskriptif, dengan pendekatan kualitatif dan penelitian kuantitatif. Karakteristik dari penelitian deskriptif yaitu 1) menggambarkan fenomena apa adanya dengan cara menelaah secara ketat dan teratur, cermat, dan 
mengutamakan obyektivitas, 2) tidak ada perlakuan yang diberikan atau dikendalikan, dan tidak ada uji hipotesis (Furchan, 2004).

\section{Tahapan Penelitian}

1. Isolasi khamir

Penelitian dilaksanakan dengan mengisolasi khamir dari semua sampel pada suhu $30^{\circ} \mathrm{C}$ selama 1 hari (24 jam). Setelah itu dilakukan pengamatan dan diambil 1 ose isolat yang memiliki ciri-ciri menyerupai khamir dan di gores pada media YPGA + Chlorampenicol $0.05 \%$ dengan metode streak radian, hingga didapatkan koloni tunggal.

2. Identifikasi isolat khamir secara mikroskopis dan makroskopis

Koloni tunggal hasil isolasi digunakan untuk identifikasi mikroorganisme secara mikroskopis dan makroskopis (warna, tekstur, penampakan permukaan, bentuk koloni, dan tepi koloni).

3. Penentuan kurva pertumbuhan isolat khamir

Kurva pertumbuhan digunakan untuk mengetahui fase log sebagai penentuan waktu inokulasi pada proses fermentasi etanol.

4. Skrining isolat khamir, analisis thermotolerant dan ethanol-tolerant (Modifikasi KeoOudone et al, 2016)

Skrining khamir dilakukan pada suhu tinggi dengan peningkatan suhu secara bertahap hingga suhu $45^{\circ} \mathrm{C}$. Isolat yang dapat tumbuh dengan baik pada suhu $45^{\circ} \mathrm{C}$ dipilih untuk dilakukan uji lanjut toleransi terhadap etanol dan suhu. Pengujian thermotolerant dilakukan pada suhu $37^{\circ} \mathrm{C}, 40^{\circ} \mathrm{C}, 45^{\circ} \mathrm{C}, 48^{\circ} \mathrm{C}$ dan $50^{\circ} \mathrm{C}$. Pengujian juga dilakukan pada etanol konsentrasi $0 \%, 1.5 \%, 3 \%, 4.5 \%, 6 \%, 7 \%, 8 \%, 9 \%, 10 \%, 11 \%, 12 \%, 13 \%, 14 \%$, dan $15 \%$.

5. Fermentasi dan analisis kadar etanol isolat potensial

Fermentasi etanol dilakukan pada isolat potensial thermotolerant dan ethanol-tolerant, kemudian dilakukan analisis kadar etanol dari isolat potensial dengan metode Gas Chromatography (GC).

\section{Prosedur Analisis}

Pada penelitian menggunakan prosedur isolasi khamir (metode gores), identifikasi mikroskopis dan makroskopis koloni, penentuan kurva pertumbuhan koloni, skrining khamir thermotolerant dan ethanol-tolerant menggunakan teknik spotting test (Nurcholis et al, 2019), suhu dan konsentrasi etanol yang digunakan untuk skrining merupakan modifikasi dari KeoOudone et al, 2016. Fermentasi dan analisis kadar etanol pada perlakuan terbaik (modifikasi Keo-oudone et al, 2016). Data yang diperoleh akan dianalisis menggunakan metode deskriptif, disajikan dalam bentuk tabel, dan diklasifikasikan sehingga merupakan suatu susunan urutan data untuk memudahkan interpretasi hasil pengamatan.

\section{HASIL DAN PEMBAHASAN}

\section{Isolasi Khamir}

Isolasi khamir dilakukan pada media YPGA yang telah diberi chlorampenicol $0.05 \%$. Sumber isolat berasal dari buah kenitu, pisang, pepaya, sawo, manggis, nangka, kesemek, siwalan, bit, mangga gadung, bengkuang, mangga manalagi, mangga podang dan cokelat. Setelah mendapatkan isolat dari berbagai sumber buah, kemudian dilanjutkan pada skrining awal menggunakan suhu $37^{\circ} \mathrm{C}, 40^{\circ} \mathrm{C}$, dan $45^{\circ} \mathrm{C}$ untuk mengetahui dan mendapatkan isolat yang dapat bertahan sampai suhu $45^{\circ} \mathrm{C}$. Isolat yang dapat tumbuh hingga suhu $45^{\circ} \mathrm{C}$ disajikan pada Tabel 1.

Tabel 1. Isolat khamir hasil screening yang dapat tumbuh pada suhu $45^{\circ} \mathrm{C}(\mathrm{b} / \mathrm{v})$. 
Isolasi dan Identifikasi Khamir Thermotolerant - Nurcholis, dkk Jurnal Pangan dan Agroindustri Vol.8 No.3: 122-133, Juli 2020

\begin{tabular}{cc}
\hline Sumber Isolat & Kode Isolat \\
\hline Kenitu & JCBI-01 \\
Pisang & JCBI-02 \\
Pepaya & JCBI-03 \\
Cokelat & JCBI-14 \\
\hline
\end{tabular}

\section{Identifikasi Isolat Khamir Secara Makroskopis dan Mikroskopis}

Isolat yang telah didapatkan selanjutnya dianalisis morfologinya secara makroskopis (Tabel 2 dan Gambar 1) dan mikroskopis (Tabel 3 dan Gambar 2).

Tabel 2. Morfologi koloni khamir yang dapat tumbuh pada suhu $45^{\circ} \mathrm{C}$

\begin{tabular}{|c|c|c|c|c|c|c|}
\hline \multirow{2}{*}{$\begin{array}{c}\text { Kode } \\
\text { Sampel }\end{array}$} & \multicolumn{6}{|c|}{ Morfologi } \\
\hline & Bentuk & Warna & Elevasi & Tepian & Konfigurasi & Kenampakan \\
\hline JCBI-01 & Sirkuler & $\begin{array}{l}\text { Putih } \\
\text { Bening }\end{array}$ & $\begin{array}{l}\text { Meninggi } \\
\text { (Raised) }\end{array}$ & $\begin{array}{c}\text { Rata } \\
\text { (Entire) }\end{array}$ & $\begin{array}{l}\text { Halus / } \\
\text { Licin }\end{array}$ & Kilap \\
\hline JCBI-02 & Sirkuler & Krem & Cembung & $\begin{array}{l}\text { Rata } \\
\text { (Entire) }\end{array}$ & $\begin{array}{l}\text { Halus / } \\
\text { Licin }\end{array}$ & Kusam \\
\hline JCBI-03 & Sirkuler & $\begin{array}{l}\text { Putih } \\
\text { krem }\end{array}$ & Cembung & $\begin{array}{l}\text { Rata } \\
\text { (Entire) }\end{array}$ & $\begin{array}{l}\text { Halus / } \\
\text { Licin }\end{array}$ & Kusam \\
\hline JCBI-14 & Sirkuler & $\begin{array}{l}\text { Putih } \\
\text { Bening }\end{array}$ & $\begin{array}{c}\text { Meninggi } \\
\text { (Raised) }\end{array}$ & $\begin{array}{l}\text { Rata } \\
\text { (Entire) }\end{array}$ & $\begin{array}{l}\text { Halus / } \\
\text { Licin }\end{array}$ & Kilap \\
\hline
\end{tabular}

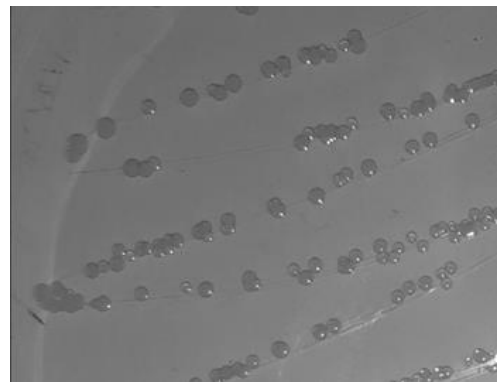

(a)

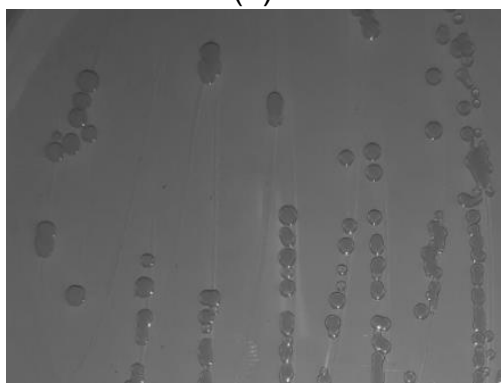

(c)

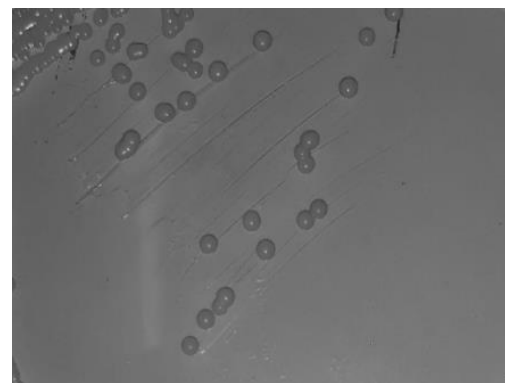

(b)

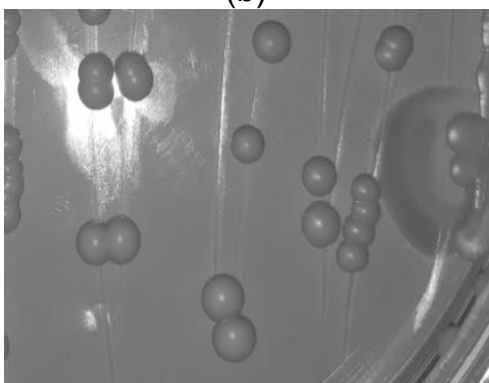

(d)

Gambar 1. Morfologi makroskopis koloni isolat khamir yang dapat tumbuh di suhu $45^{\circ} \mathrm{C}$ Keterangan: Isolat (a) JCBI-01, (b) JCBI-02, (c) JCBI-14, (d) JCBI-03.

Tabel 3. Morfologi mikroskopis sel khamir yang dapat tumbuh pada suhu $45^{\circ} \mathrm{C}$

\begin{tabular}{cccc}
\hline $\begin{array}{c}\text { Kode } \\
\text { Isolat }\end{array}$ & Bentuk Sel & Pola Pertunasan & Pseudohifa dan hifa sejati \\
\hline JCBI-01 & $\begin{array}{c}\text { Oval-memanjang } \\
\text { Silindris } \\
\text { Bulat } \\
\text { semi bulat }\end{array}$ & Multilateral & Hifa sejati \\
$\mathrm{JCBI}-02$ & $\begin{array}{c}\text { Multilateral } \\
\text { Semi bulat } \\
\mathrm{JCBI}-14\end{array}$ & Multilateral & - \\
$\mathrm{JCBI}-03$ & $\begin{array}{c}\text { Silindris } \\
\text { Bulat }\end{array}$ & Multilateral & Pseudohifa \\
\hline
\end{tabular}




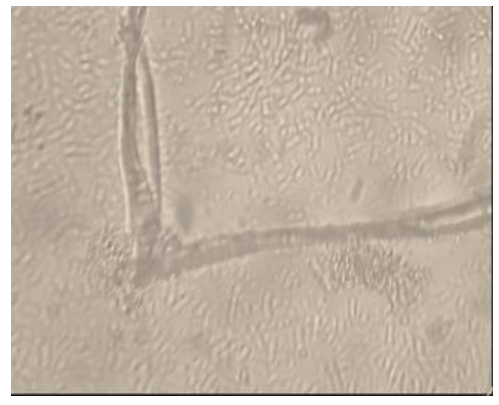

(a)

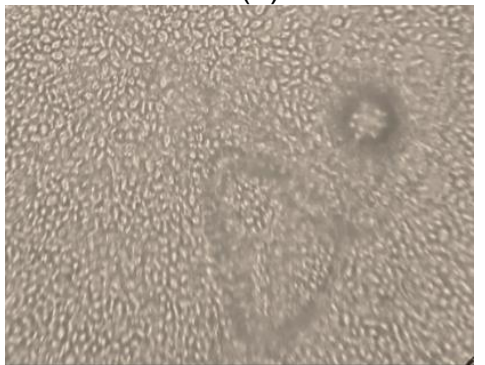

(c)

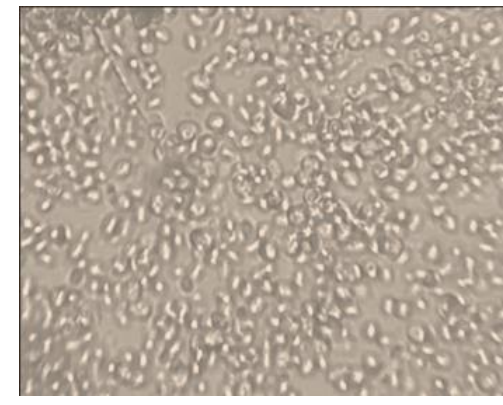

(b)

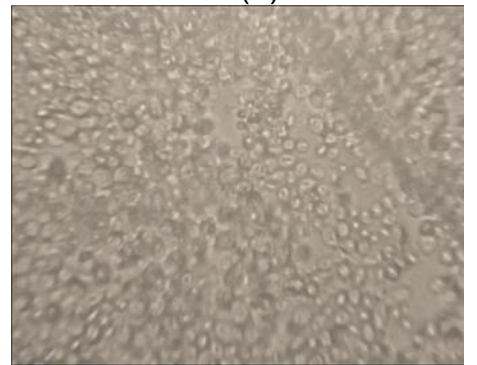

(d)

Gambar 2. Morfologi mikroskopis sel khamir yang dapat tumbuh pada suhu $45^{\circ} \mathrm{C}$ (a) JCBI-01, (b) JCBI-02, (c) JCBI-14, (d) JCBI-03.

Berdasarkan data yang disajikan pada Tabel 2 dan Tabel 3, serta Gambar 1 dan Gambar 2. Isolat dengan kode JCBI-01 dan JCBI-14 memiliki kemiripan karakter dengan genus Candida $s p$ karena memiliki bentuk koloni sirkuler, berwarna putih bening, elevasi meninggi (raised), tepian rata (entire), konfigurasi halus/licin, dan kenampakan kilap. Sedangkan morfologi selnya oval-memanjang/semi bulat dan silindris dengan pola pertunasan multilateral, serta memiliki hifa dan pseudohifa. Karakteristik ini sesuai dengan Barnett et al (1990) dan Talaro et al (2012) bahwa Candida memiliki koloni putih sampai krem dan membentuk tunas. Barnett et al (1990) menyatakan Candida tropicalis koloni bulat, reproduksi vegetatif dan tidak memiliki reproduksi seksual. Prasad (2005) genus Candida seringkali membentuk pseudohifa maupun hifa. Genus ini merupakan khamir yang memiliki diversivitas cukup tinggi.

Pada isolat JCBI-02 dan JCBI-03 jika merujuk pada Gambar 2 memiliki kemiripan karakter dengan genus Saccharomyces karena memiliki bentuk koloni sirkuler, berwarna putih bening, elevasi cembung, tepian rata (entire), konfigurasi halus/licin, dan kenampakan kusam. Sedangkan morfologi selnya bulat-semi bulat dengan pola pertunasan multilateral. Hal ini sesuai dengan Kurtzman (1998) dan Nurhayati (2004) yang menyebutkan bahwa genus Saccharomyces melakukan reproduksi vegetatif dengan multilateral budding globase, elips, atau silindris, bulat dan oval. Koloni genus ini memiliki tekstur kental dan tidak memiliki pigmen karoteniod. Genus ini memiliki kemampuan fermentasi anaerob atau semi anaerob pada satu atau lebih jenis gula unutk menghasilkan etanol dan $\mathrm{CO}_{2}$. Sehingga dapat disimpulkan bahwa isolat JCBI-01 merupakan genus Saccharomyces. Pernyataan tersebut didukung oleh penelitian Brooks (2008) yang mengisolasi khamir dari buah pisang dikemukakan bahwa khamir yang terdapat pada buah pisang yakni $S$. cerevisiae R-8, $S$. cerevisiae R-2, $S$. cerevisiae T-7, S. kluyveri K-6 dan $D$. hansenii B-2. Penelitian yang dilakukan oleh Parameswari (2015) yang mengisolasi khamir dari buah pepaya dikemukakan bahwa khamir yang terdapat pada pepaya yakni jenis Sacharomyces sp.

\section{Kurva Pertumbuhan Isolat Khamir}

Kurva pertumbuhan masing-masing isolat disajikan pada Gambar 3. Semua isolat mengalami tiga fase dalam waktu pertumbuhan 24 jam yakni fase adaptasi (lag), fase eksponensial (log), dan fase stasioner. Kurva pertumbuhan isolat JCBI-01, JCBI-02, JCBI-14, 
dan JCBI-03 yang telah didapatkan akan dijadikan sebagai dasar waktu inokulasi dalam tahap produktifitas etanol yang terbaik saat isolat mengalami fase eksponensial (log) terakhir sebelum fase stasioner. Berdasarkan Gambar 3 dapat ditentukan waktu yang tepat untuk inokulasi dalam produktifitas etanol yakni jam ke-16 untuk isolat JCBI-01, jam ke-12 untuk isolat JCBI-02, jam ke-12 untuk isolat JCBI-14, dan jam ke-30 untuk isolat JCBI-03 (data tidak ditunjukkan). Perbedaan fase eksponensial dikarenakan perbedaan jenis isolat sehingga karakteristik masing-masing isolat juga berbeda, salah satunya yakni kecepatan pertumbuhan isolat. Penuangan inokulum sebaiknya dilakukan pada saat pertumbuhan logaritmik karena menurut Dwijoseputro (2010) pada fase tersebut pembiakan mikroorganisme berlangsung sangat cepat sehingga mikroorganisme yang berada pada fase ini cocok dijadikan inokulum.

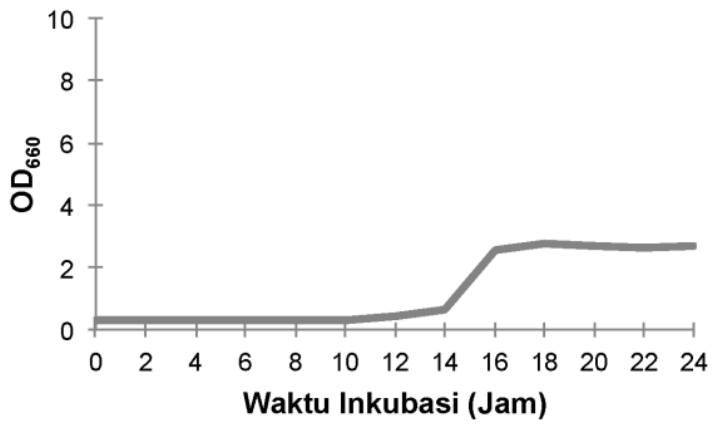

(a)

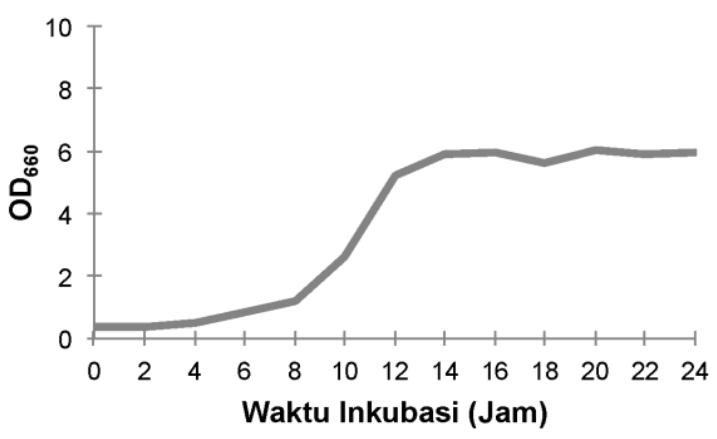

(c)

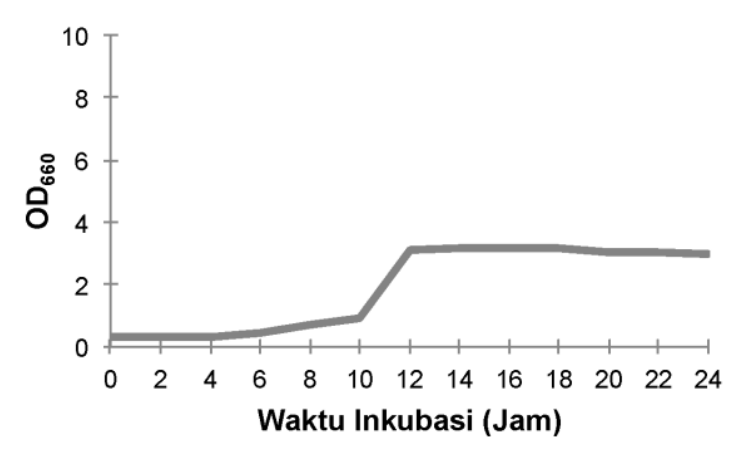

(b)

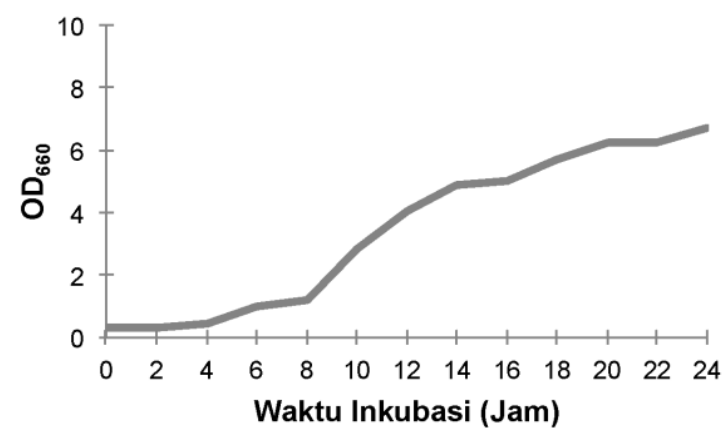

(d)

Gambar 3. Kurva Pertumbuhan Isolat Khamir (a) JCBI-01, (b) JCBI-02, (c) JCBI-14, (d) JCBI-03.

\section{Uji Thermotolerant dan Ethanol-tolerant}

Thermotolerance adalah kemampuan sementara sel khamir untuk bertahan hidup pada suhu yang lebih tinggi. Strain khamir yang thermotolerance dapat bertahan hidup di suhu di atas $40^{\circ} \mathrm{C}$ (Choudhary, 2016). Hasil uji thermotolerant keempat isolat disajikan pada Tabel 4 dan Gambar 4, sedangkan hasil uji ethanol-tolerant dapat dilihat pada Tabel 5 dan Gambar 5.

Berdasarkan Tabel 4 dan Gambar 4, isolat JCBI-01 (Kenitu), JCBI-02 (Pisang), JCBI14 (Coklat), dan JCBI-03 (Pepaya) dapat tumbuh baik dengan ditunjukkan empat tanda positif $(++++)$ sampai pada suhu $48^{\circ} \mathrm{C}$. Namun, semua isolat khamir yang diperoleh tidak dapat tumbuh pada suhu $50^{\circ} \mathrm{C}$. Fenomena ini juga di dukung oleh penelitian Caspeta dan Nielsen (2015) yang menyatakan bahwa analisis komputasional dari sifat fisik protein menunjukkan bahwa suhu mematikan untuk khamir adalah sekitar $49^{\circ} \mathrm{C}$. Hal ini karena sebagian besar dari protein khamir terdenaturasi di atas suhu ini. Khamir thermotolerance yang diisolasikan dengan menggunakan metode adaptasi fisiologi ke suhu $>40^{\circ} \mathrm{C}$ dapat ditemukan memiliki komposisi sterol yang berubah. Modifikasi dalam komposisi dalam komposisi sterol khamir dianggap dapat mempertahankan fluiditas membran sel pada suhu tinggi, sehingga mengakibatkan peningkatan thermotolerance (Caspeta et al, 2014). 
Tabel 4. Hasil Uji Thermotolerant Isolat JCBI-01, JCBI-02, JCBI-14, dan JCBI-03

\begin{tabular}{lllllc}
\hline \multicolumn{1}{c}{ Isolat } & $\mathbf{3 7}^{\circ} \mathbf{C}$ & $\mathbf{4 0}^{\circ} \mathbf{C}$ & $\mathbf{4 5}^{\circ} \mathbf{C}$ & $\mathbf{4 8 ^ { \circ } \mathbf { C }}$ & $\mathbf{5 0} \mathbf{C}$ \\
\hline $\begin{array}{l}\mathrm{JCBI}-01 \\
\text { (kenitu) }\end{array}$ & ++++ & ++++ & ++++ & ++++ & - \\
$\begin{array}{l}\mathrm{JCBI}-02 \\
\text { (pisang) }\end{array}$ & ++++ & ++++ & ++++ & ++++ & - \\
$\begin{array}{l}\mathrm{JCBI}-14 \\
\text { (coklat) }\end{array}$ & ++++ & ++++ & ++++ & ++++ & - \\
$\begin{array}{l}\mathrm{JCBl}-03 \\
\text { (pepaya) }\end{array}$ & ++++ & ++++ & ++++ & ++++ & - \\
\hline
\end{tabular}

Keterangan : $(++++)$ isolat yang mampu hidup dengan sangat baik

$(+++)$ isolat yang mampu hidup dengan cukup baik

$(++)$ isolat yang mampu hidup dengan baik

(-) isolat yang tidak dapat hidup

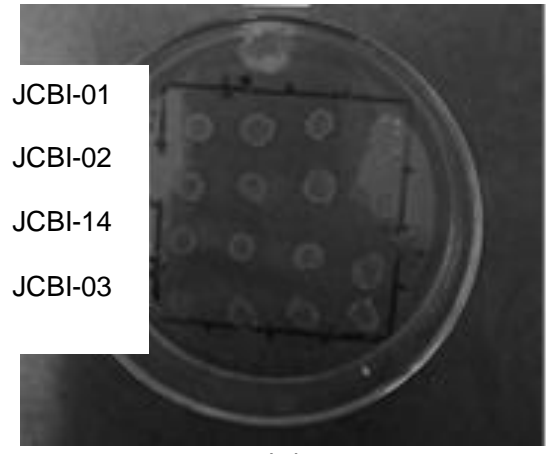

(a)

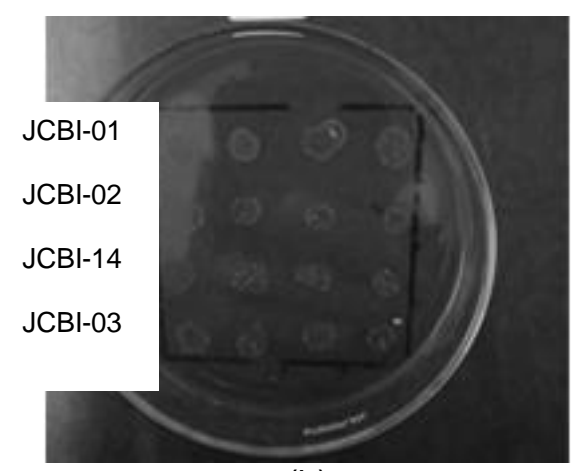

(b)

Gambar 4. Pertumbuhan Koloni Isolat pada suhu $45^{\circ} \mathrm{C}$ dan $48^{\circ} \mathrm{C}$

Sel khamir akan merespon dengan cepat pada tingkatan molekuler ketika mengalami peningkatan suhu secara tiba-tiba pada pertumbuhan. Hal ini disebut respon heat-shock. Fenomena pengaturan ini terjadi pada semua sel hidup. Perlakuan peningkatan suhu secara tiba-tiba yang dilakukan secara step by step mengarah pada induksi dan ekspresi gen yang bertanggung jawab untuk sintesis heat-shock proteins (HSPs) (Choudhary, 2016). Karena khamir merupakan sel mikroba yang termasuk dalam mesofilik, perlakuan uji thermotolerant menunjukkan efisiensi fermentasi yang buruk pada suhu tinggi $\left(>35^{\circ} \mathrm{C}\right)$. Hal ini disebabkan oleh meningkatnya fluiditas membran sitoplasma yang kemudian direspon oleh sel khamir dengan memodifikasi komposisi asam lemaknya (Choudhary, 2016).

Oleh karena itu beberapa perubahan sel yang disebabkan oleh perlakuan suhu tinggi pada akhirnya akan mempengaruhi struktur dan fungsi protein, menghasilkan protein abnormal dan pada akhirnya mengakibatkan penghambatan pertumbuhan atau kematian sel khamir itu sendiri. Toleransi terhadap suhu tinggi sebagian besar dikendalikan oleh aktivasi dan regulasi gen-gen yang terkait pada stres spesifik. Gen-gen ini memainkan peranan penting dalam sintesis senyawa spesifik yang melindungi organisme dari stres terhadap suhu tinggi (Araque et al, 2008). Setelah dilakukannya perlakuan peningkatan suhu secara bertahap, sel khamir selain melakukan sintesis HSPs, sel-sel khamir mulai mengumpulkan senyawa pelindung lainnya seperti trehalose bersama dengan enzim yang terkait seperti mitrokondria superoksida dismutase dan katalase. Trehalose dianggap sebagai thermoprotectant, karena membantu menstabilkan membran sitoplasma dan protein seluler (Walker, 1998). Secara umum, khamir bersifat mesofilik dengan batas suhu pertumbuhan antara $28^{\circ} \mathrm{C}$ dan $38^{\circ} \mathrm{C}$. Ini merupakan alasan mengapa suhu operasi harus dijaga antara $30^{\circ} \mathrm{C}$ dan $35^{\circ} \mathrm{C}$ dalam reaktor fermentasi khamir yang khas (Ueno et al, 2002). Sehingga dapat disimpulkan bahwa semua isolat yang di uji pada penelitian ini memiliki kemampuan thermotolerant. 
Berdasarkan Tabel 5 dan Gambar 5 menunjukkan bahwa isolat JCBI-01 (Kenitu), JCBI-02 (Pisang), JCBI-14 (Coklat), dan JCBI-03 (Pepaya) dapat tumbuh baik dengan ditunjukkan empat tanda positif (++++) sampai konsentrasi etanol pada media pertumbuhan sebesar $14 \%$ (v/v) pada uji ethanol tolerant yang pertama maupun lanjutan. Hal ini disebabkan karena konsentrasi $4.5-12 \%$ merupakan rata-rata strain khamir pada buah-buah tersebut dapat toleran terhadap etanol. Fenomena tersebut sesuai dengan Unaldi et al (2002) melaporkan bahwa isolat dari buah seperti anggur dan apel memiliki tingkat toleransi etanol $9-12 \%$.

Tabel 5. Uji Ethanol-tolerant Isolat pada konsentrasi etanol $11-15 \%$

\begin{tabular}{lccccc}
\hline Sampel & $\mathbf{1 1 \%}$ & $\mathbf{1 2 \%}$ & $\mathbf{1 3 \%}$ & $\mathbf{1 4 \%}$ & $\mathbf{1 5 \%}$ \\
\hline $\begin{array}{l}\text { JCBI-01 } \\
\text { (kenitu) }\end{array}$ & ++++ & ++++ & ++++ & ++++ & +++ \\
$\begin{array}{l}\text { JCBI-02 } \\
\text { (pisang) }\end{array}$ & ++++ & ++++ & ++++ & ++++ & - \\
$\begin{array}{l}\text { JCBI-14 } \\
\text { (coklat) }\end{array}$ & ++++ & ++++ & ++++ & ++++ & + \\
JCBI-03 & & & & - \\
(pepaya) & ++++ & ++++ & ++++ & ++++ & \\
\hline
\end{tabular}

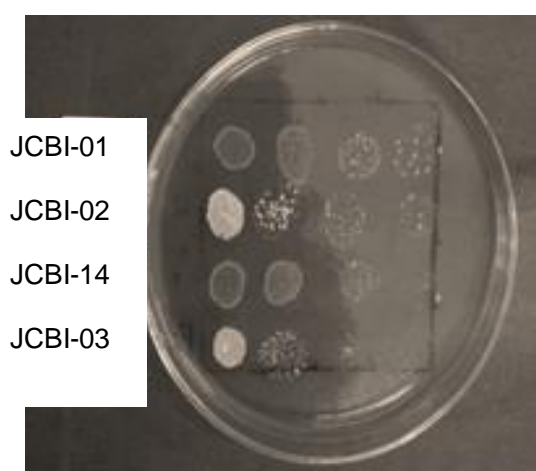

(a)

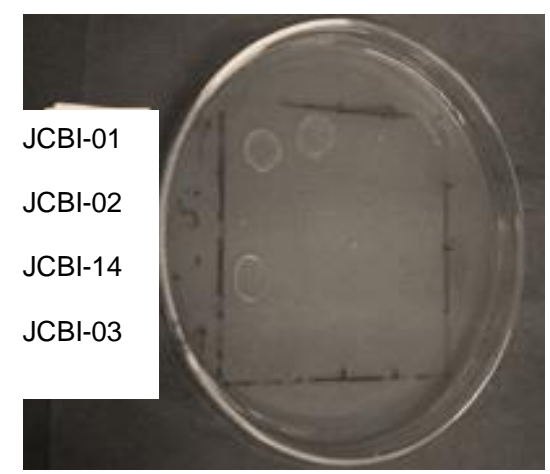

(b)

Gambar 5. Pertumbuhan Koloni Isolat Khamir pada Konsentrasi Etanol a) $14 \%$ dan b) 15\%

Sel khamir dapat toleran pada etanol disebabkan oleh sifat fisik sel pada khamir dikelilingi oleh dinding sel yang terdiri dari mannoprotein dan glukan yang dapat memberikan bentuk pada sel khamir. Selain itu juga memberikan perlindungan mekanis dan termal dari lingkungan. Selanjutnya, dinding sel dapat mencegah terjadinya tekanan turgor yang mungkin akan membahayakan membran sel (Cabib et.al, 1991).

Pada media pertumbuhan dengan konsentrasi $15 \%(\mathrm{v} / \mathrm{v})$ semua isolat mengalami penurunan dalam pertumbuhan yang drastis, sehingga hanya isolat $\mathrm{JCBI}-01$ dan $\mathrm{JCBI}-14$ masih dapat tumbuh dengan ditunjukkan tiga tanda positif $(+++)$ untuk isolat $\mathrm{JCBI}-01$ yang dapat diartikan bahwa isolat tumbuh sampai dengan pengenceran $10^{-2}$. Sedangkan untuk isolat JCBI-14 masih bisa tumbuh dengan ditunjukkan satu tanda positif (+) yang dapat diartikan bahwa isolat tumbuh sampai dengan pengenceran $10^{-0}$ saja. Menurut Dalawai (2017) peningkatan konsentrasi dapat mempengaruhi toleransi khamir pada etanol, Secara umum pengaruh etanol terhadap khamir dapat menurunkan laju pertumbuhan dan fermentasi serta mengurangi tingkat viabilitas sel secara keseluruhan. 
Isolat JCBI-01 (Kenitu) dan JCBI-14 (Coklat) menunjukkan bahwa sel khamir dapat bertahan hidup meskipun kondisi lingkungan yang ekstrem (suhu, $\mathrm{pH}$, dan konsentrasi etanol pada bahan tinggi). Menurut Cabib et al (1991) sel khamir dapat toleran pada etanol disebabkan oleh sifat fisik sel pada khamir dikelilingi oleh dinding sel dan sumber nutrisi isolat khamir. Dinding sel mengandung berbagai enzim yang bertanggung jawab untuk mengatur metabolisme khamir, sehingga sel dapat bertahan dengan lingkungan yang ekstrem dan memungkinkan terjadi reproduksi dan dapat tumbuh pada kondisi tersebut. Penelitian Nasreen (2014) menyatakan bahwa protein adalah nutrisi penting untuk pertumbuhan khamir, sementara lemak sangat penting untuk struktur dan fungsi biologis sel dan dapat dimanfaatkan sebagai sumber energi alternatif oleh sel saat metabolisme maupun reproduksi. Aguilera et al. (2006) juga menyatakan bahwa kemampuan sel khamir untuk meningkatkan konsentrasi asam lemak tak jenuh dalam plasma membran adalah mekanisme utama yang digunakan oleh khamir untuk beradaptasi dengan kehadiran etanol konsentrasi tinggi dan meningkatkan toleransi sel khamir terhadap senyawa etanol.

Sehingga dapat disimpulkan bahwa isolat yang toleran terhadap etanol adalah isolat JCBI-01 (Kenitu) dan JCBI-14 (Coklat). Fenomena ini sesuai dengan penelitian Tikka et al (2013) jika secara umum khamir yang dilakukan uji etanol toleran berada pada level toleransi etanol dengan konsentrasi $0 \%$ sampai $12 \%(\mathrm{v} / \mathrm{v})$. Meskipun beberapa strain khamir toleran sampai dengan kadar etanol $14.5 \%$ dengan tingkat pertumbuhan yang sangat kurang. Hal ini didukung dengan penilitian Dalawai et al (2017) yang melakukan isolasi 40 khamir dari berbagai macam buah, bahwa khamir tumbuh sangat baik pada media yang mengandung 8$15 \%$ etanol.

\section{Uji Produktifitas Etanol}

Setelah dilakukan uji thermotolerant dan ethanol-tolerant, maka dilaksanakan proses fermentasi etanol pada media YP dengan konsentrasi glukosa $10 \%(\mathrm{~b} / \mathrm{v})$ dengan suhu fermentasi $40^{\circ} \mathrm{C}$ selama 48 jam. Konsentrasi etanol selama fermentasi diukur menggunakan metode Gas Chromatography dan hasilnya disajikan pada Tabel 6.

Tabel 6. Konsentrasi Etanol (Media YP $+10 \%$ Glukosa pada $40^{\circ} \mathrm{C}$ )

\begin{tabular}{lccc}
\hline \multirow{2}{*}{ Kode Isolat } & \multicolumn{3}{c}{ Konsentrasi etanol (\% b/v) } \\
\cline { 2 - 4 } & $\mathbf{1 2}$ Jam & 24 Jam & 48 Jam \\
\hline JCBI-01 (Kenitu) & 0.44 & 0.47 & 2.41 \\
JCBI-02 (Pisang) & 0.47 & 1.15 & 2.54 \\
JCBI-14 (Coklat) & 1.61 & 2.41 & 2.63 \\
JCBI-03 (Pepaya) & 1.10 & 2.47 & 3.07 \\
\hline
\end{tabular}

Berdasarkan data yang telah disajikan pada Tabel 6 dapat diketahui semua isolat paling tinggi produksinya pada 48 jam fermentasi yakni pada isolat $\mathrm{JCBI}-01$ (kenitu) sebesar $2.41 \%(\mathrm{~b} / \mathrm{v})$, JCBI-02 (pisang) 2.54\% (b/v), JCBI-14 (cokelat) 2.63\% (b/v), dan JCBI-03 (pepaya) $3.07 \%(\mathrm{~b} / \mathrm{v})$. Perbandingan dengan beberapa hasil penilitian diantaranya Brooks (2008) yang menggunakan strain isolat Saccharomyces cerevisiae R-8 menghasilkan etanol $4.8 \%(\mathrm{~b} / \mathrm{v})$ dengan media fermentasi mengandung $15 \%$ glukosa pada $40^{\circ} \mathrm{C}$ dan Sanchez et al (2002) menggunakan isolat $C$. shehatae pada media $20 \%$ glukosa pada suhu $30^{\circ} \mathrm{C}$ dapat menghasilkan etanol sebesar $1.4 \%$ (b/v). Sedangkan pada isolat $K$. marxianus DMKU3-1042 (Keo-oudone et al, 2016) menghasilkan 5.2\% (b/v) dengan menggunakan media 16\% glukosa pada suhu $40^{\circ} \mathrm{C}$.

Gambar 6 menunjukan hasil kromatogram dari masing-masing hasil fermentasi etanol selama 48 jam. Gambar (a) menunjukkan hasil kromatogram dari senyawa etanol dengan peak yang muncul pada menit 7.71 dan \% area sebesar 5.45. Gambar (b) menunjukkan hasil kromatogram dari senyawa etanol dengan peak yang muncul pada menit 7.75 dan \% area sebesar 5.77. Gambar (c) menunjukkan hasil kromatogram dari senyawa etanol dengan peak yang muncul pada menit 7,72 dan \% area sebesar 5,73. Gambar (d) menunjukkan hasil 
kromatogram dari senyawa etanol dengan peak yang muncul pada menit 7,74 dan $\%$ area sebesar 6,96.

Hasil komparasi antara hasil penelitian yang telah dilakukan dan penelitian pembanding dapat diketahui bahwa isolat JCBI-01 (kenitu), JCBI-02 (pisang), JCBI-14 (cokelat), dan JCBI-03 (pepaya) memiliki kemampuan produksi etanol yang kecil atau sedikit. Akan tetapi dari semua isolat yang paling tinggi produktifitasnya pada suhu tinggi yakni isolat JCBI-03 (pepaya) dengan hasil etanol sebesar 3.07\% (b/v). Perbedaan ini disebabkan oleh beberapa faktor yakni yang pertama ialah banyaknya substrat pada media fermentasi yang relatif lebih sedikit dan suhu yang digunakan untuk fermentasi tergolong tinggi untuk khamir. Pernyataan tersebut didukung oleh pernyaataan Adam and Moss (1995) yang menyatakan bahwa konsentrasi etanol yang diperoleh dari proses fermentasi dipengaruhi oleh kadar gula sebagai substratnya. Pernyataan lain yang mendukung yakni Ueno et al (2002) yang menyatakan bahwa secara umum khamir merupakan mikroorganisme bersifat mesofilik dengan batas suhu pertumbuhan antara $28^{\circ} \mathrm{C}$ sampai $38^{\circ} \mathrm{C}$. Faktor kedua yang mempengaruhi perbedaan hasil dipengaruhi oleh perbedaan spesies dan strain khamir yang digunakan serta sumber substrat yang berbeda. Hal ini didukung oleh pernyataan Keooudone et al (2016) yang melakukan penelitian pada 32 strain khamir dari 4 spesies khamir yang berbeda serta ditumbuhkan pada media glukosa, air tebu, sukrosa, dan molase menyatakan bahwa semua strain khamir memperlihatkan perbedaan kemampuan fermentasi etanol pada sumber karbon yang berbeda.

Pada proses respirasi dan fermentasi diatur oleh faktor lingkungan, terutama glukosa dan konsentrasi oksigen. Saat proses respirasi, piruvat didekarboksilasi dalam mitokondria ke asetil-KoA. Kemudian akan benar-benar teroksidasi dalam siklus Krebs menjadi $\mathrm{CO}_{2}$, energi, dan intermediet untuk mendorong pertumbuhan khamir. Pada saat proses fermentasi glukosa secara perlahan digunakan untuk menghasilkan energi yang dibutuhkan hanya untuk menjaga sel khamir tetap hidup (Bekatorou et al, 2006). Ketika konsentrasi glukosa cukup tinggi, enzim yang digunakan dalam respirasi ditekan dan proses fermentasi mengambil alih proses respirasi (Bekatorou et al, 2006). Setelah etanol terbentuk, ia disekresikan ke dalam media pertumbuhan serta berbagai produk sampingan lain dari fermentasi seperti gliserol, asam asetat, $\mathrm{H}_{2} \mathrm{~S}$ dan ester.

\section{SIMPULAN}

Hasil penelitian menunjukkan bahwa isolat JCBI-01 (kenitu) dan JCBI-14 (coklat) diduga genus Candida sp, sedangkan isolat JCBI-02 (pisang) dan JCBI-03 (pepaya) diduga genus Saccharomyces sp. Pada uji ethanol-tolerant isolat JCBI-01, JCBI-02, JCBI-14, dan $\mathrm{JCBI}-03$ memiliki toleransi yang baik terhadap etanol 14\%, sedangkan isolat JCBI-01 dan $\mathrm{JCBI}-14$ masih toleran pada konsentrasi $15 \%$. Pada uji thermotolerant semua isolat bertahan hingga suhu $48^{\circ} \mathrm{C}$. Untuk kemampuan dalam produksi etanol pada jam ke-48 isolat JCBI-01 sebesar $2.41 \%(\mathrm{~b} / \mathrm{v})$, isolat $\mathrm{JCBI}-02$ sebesar $2.54 \%(\mathrm{~b} / \mathrm{v})$, JCBI-14 sebesar $2.63 \%(\mathrm{~b} / \mathrm{v})$, dan $\mathrm{JCBI}-03$ sebesar $3.07 \%(\mathrm{~b} / \mathrm{v})$. Selain itu perlu dilakukannya identifikasi isolat khamir secara molekuler diantaranya metode MALDI-TOFF atau sekuensing daerah 26SrDNA.

\section{DAFTAR PUSTAKA}

Adam, M.R., \& Moss M.O. 1995. Food microbiology. London: The Royal Society of Chemistry. Cambridge.

Aguilera, F., Peinado, R.A., Millan, C., Ortega, J.M., \& Mauricio, J.C. 2006. Relationship between ethanol tolerance, $\mathrm{H}^{+}$-ATPase activity and the lipid composition of the plasma membrane in different wine yeast strains. Int $J$ of Food Microbiol, 110:1, 34-42.

Araque, E., Parra, C., Rodríguez, M., Freer, J., \& Baeza, J. 2008. Selection of thermotolerant yeast strains Saccharomyces cerevisiae for bioethanol production. Enzyme Microbiol Technol, 43,120-123. 
Banat, I.M., Nigam, P., Singh, D., Marchant, R., \& McHale, A.P. 1998. Ethanol production at elevated temperatures and alcohol concentrations: Part I-yeasts in general. World $J$ Microbiol Biotechnol, 14, 809-821.

Barnett, J.A, Payne, R.W., \& Yarrow, D. 1990. Yeast: Characteristics \& Identification. $2^{\text {nd }}$ Ed. London: Cambridge University Press.

Bekatorou, A., Psarianos, C., \& Koutinas, A.A. 2006. Production of food grade yeasts. Food Technol Biotechnol, 44:3, 407-415.

Brooks, A.A. 2008. Ethanol production potential of local yeast strains isolated from ripe banana peels. Afr J Biotechnol. 7, 3749-3752.

Cabib, E., Silverman, J., Shaw, A., Das Gupta, S., Park, H.-M., Mullins, T., Mol, P.C., \& Bowers, B. 1991. Carbohydrates as structural constituents of yeast cell wall and septum. Pure Appl Cheni, 63, 483-489.

Caspeta, L., Chen, Y., Ghiaci, P., Feizi, A., Buskov, S., Hallstrüm, B.M., \& Nielsen J. 2014. Altered sterol composition renders yeast thermotolerant. Science, 346, 75. doi: 10.1126/science.1258137.

Caspeta, L., \& Nielsen, J. 2015. Thermotolerant yeast strains adapted by laboratory evolution show trade-off at ancestral temperatures and preadaptation to other stresses. $\mathrm{mBio}$, 6:4, 00431-15. doi:10.1128/mBio.00431-15.

Choudhary, J., Singh, S., \& Nain L. 2016. Thermotolerant fermenting yeasts for simultaneous saccharification fermentation of lignocellulosic biomass. Electron J Biotechnol 21, 8292.

Dalawai, N. Krupa, K. N., Nadkarni, S., Bharani, S., \& Harinikumar, K. M. 2017. Screening of efficient ethanol tolerant yeast strain for production of ethanol. Int $J$ Pure App Biosci $5: 1,744-752$.

Dwijoseputro, D. 2010. Dasar-dasar Mikrobiologi. Jakarta: Djambatan.

Furchan, A. 2004. Pengantar Penelitian dalam Pendidikan. Yogyakarta: Pustaka Pelajar.

Kementerian ESDM. 2016. Statistik Minyak dan Gas Bumi. Direktorat Minyak dan Gas Bumi. Kementerian Energi dan Sumber Daya Mineral. Jakarta.

Keo-oudone, C., Nitiyon, S., Sotitham, P., Tani, A., Lertwattanasakul, N., Yuangsaard, N., Bounphanmy, S., Limtong, S., \& Yamada M. 2016. Isolation and characterization of thermotolerant ethanol-fermenting yeasts from Laos and application of whole-cell matrix-assisted laser desorption/ionization time-of-flight mass spectrometry (MALDITOF/MS) analysis for their quick identification. Afr J Biotechnol, 15:6, 153-164. doi: 10.5897/AJB2015.14984.

Kosaka, T., Lertwattanasakul, N., Rodrussamee, N., Nurcholis, M., Dung, N.T.P., KeoOudone, C., Murata, M., Gotz, P., Theodoropoulos, C., Suprayogi, Maligan, J.M., Limtong, S., \& Yamada, M. 2018. Potential of thermotolerant ethanologenic yeasts isolated from ASEAN countries and their application in high-temperature fermentation. Book Chapter Intech Open. doi: 10.5572/intechopen.79144.

Kurtzman, C.P. \& Fell, J.W. 1998. The yeast a taxonomy study. New York: Elvesier

Limtong, S., Sringiew, C., \& Yongmanitchai, W. 2007. Production of fuel ethanol at high temperature from sugar cane juice by a newly isolated Kluyveromyces marxianus. Bioresour Technol 98, 3367-3374. doi: 10.1016/j.biotech.2006.10.044.

Martynova, J., Kokina, A., Kibilds, J., Liepins, J., Scerbaka, R., \& Vigants, A. 2016. Effects of acetate on Kluyveromyces marxianus DSM 5422 growth and metabolism. Appl Microbiol Biotechnol 100, 4585-4594. doi: 10.1007/s00253-016-7392-0.

Murata, M., Nitiyon, S., Lertwattanasakul, N., Sootsuwan, K., Kosaka, T., Thanonkeo, P., Limtong, S., \& Yamada, M. 2015. High temperature fermentation technology for lowcost bioethanol. J Japan Inst Energy 94, 1154-1162. doi: 10.3755/jie.94.1154.

Nasreen, Z., Jabeen, S., \& Shafique M. 2014. Production of Alcohol by yeast isolated from apple, orange, banana. IJFNS. 1:2, 016-019.

Nurcholis M., Nitiyon S., Suprayogi, Rodrussamee N., Lertwattanasakul N., Limtong S., Kosaka T., \& Yamada M. 2019. Functional analysis of Mig1 and Rag5 as expressional 
regulators in thermotolerant yeast Kluyveromyces marxianus. Applied Microbiology and Biotechnology 103, 395-410.

Nurhayati, T. 2004. Variety of oil-degraded-yeast isolated from Tanjung Perak Surabaya Harbor. Berk. Penel. Hayati 9, 87-91.

Parameswari, K., Hemalatha, M., \& Priyanka, K. 2015. Isolation of yeast and ethanol producing from papaya (Carica papaya) and grape (Vitis vinifera) fruits. Int $J$ Sci \& Engineer Res, 6:2, 100-104.

Prasad, R., \& Kapoor K. 2005. Multidrug resistance in yeast Candida. Int Rev Cytol 242, 215248.

Sanchez, S., Bravo, V., Castro, E., Moya, A.J., \& Camacho, F. 2002. The fermentation of mixtures of D-glucose and D-xylose by Candida shehatae, Pichia stipitis to produce ethanol. J Chem Technol Biotechol 77, 641-648, doi: 10. 1002/jcrb.622

Talaro, K.P., \& Chess, B. 2012. Foundation in Microbioligy, Eight Edition. McGraw-Hill

Tikka, C., Osuru, H.P., Atluri, N., Raghavulu, P.C.V., Yellapu, N.K., Ismail, S.M., Uppu, V.P., Sudheer, A., Narasimha, V.K., \& Matcha B. 2013. Isolation and Characterization Of Ethanol Tolerant Yeast Strains. doi: 10.6026/97320630009421

Ueno, R., Urano, N., \& Kimura, S. 2002. Effect Of Temperature and Cell Density On Fermentation By a Thermotolerant Aquatic Yeast Strain Isolated From a Hot Spring Environment. Fisheries Science 68, 571-578.

Unaldi, M.N., Arikan, B., \& Coral, G. 2002. Isolation of alcohol tolerant, osmotolerant and thermotolerant yeast strains and improvement of their alcohol tolerance by UV mutagenesis. Acta Microbiol Pol, 51:2, 115-120.

Walker, G.M. 1998. Yeast Physiology and Biotechnology. New York: John Wiley and Sons. 